\title{
Characterization and Evaluation of Land Resources of Valia Block, Bharuch District, Gujarat
}

\author{
G. Tiwari*, A. Jangir, R. P. Sharma, B. Dash, R. K. Naitam, L. C. Malav, \\ R. Paul, P. Chandran and S. K. Singh \\ ICAR-National Bureau of Soil Survey and Land Use Planning, Nagpur-440 033, Maharashtra, India
}

\begin{abstract}
Detailed soil survey (1:10000 scale) was carried out using base map prepared from satellite data (IRS-P6 LISS IV and Cartosat-1) and Digital Elevation Models (DEM) in conjunction with Survey of India (SOI) Toposheets of 1:50000 scale in Valia block, Bharuch district of Gujarat. On the basis of landform, slope, land use/land cover and ground truth, six landscape ecological Units (LEUs) were delineated and six soil series were identified in the block. Five soil series occur on alluvial plain (cover $66.16 \%$ ) and one soil series occupies pediplain $27.61 \%$. These series were mapped into ten soil mapping units as phases of soil series. The representative pedons of alluvial plain were moderately deep to very deep and their sand, silt and clay content ranged from 8.2 to $44.4,9.8$ to 40.2 and 43.8 to 55.6 per cent, respectively. These pedons were neutral to strongly alkaline (pH 6.8 - 9.7), nonsaline with low to high organic carbon $(0.18-1.2 \%)$ content, low to high calcium carbonate (5.9 - 26.6\%) and high CEC [ $\left.>35 \mathrm{cmol}\left(\mathrm{p}^{+}\right) \mathrm{kg}^{-1}\right]$. Exchangeable complex of these pedons were dominated by $\mathrm{Ca}^{2+}$ followed by $\mathrm{Mg}^{2+}, \mathrm{Na}^{+}$and $\mathrm{K}^{+}$cations with high base saturation (72.0 to 99. 4 \%). Soils were classified as Vertic Haplustepts, Typic Haplusterts, Typic Calciustepts, Typic Haplustepts and Sodic Haplusterts. The representative pedon of pediplains was shallow, dark brown (7.5YR3/2), clayey, strongly alkaline $(\mathrm{pH}>8.5)$, non-saline $\left(<2 \mathrm{dSm}^{-1}\right)$ and had moderate organic carbon (0.50-0.75\%) and calcium carbonate (5-15\%) with high CEC [ $\left.>35 \mathrm{cmol}\left(\mathrm{p}^{+}\right) \mathrm{kg}^{-1}\right]$ and classified as Lithic Haplustepts. The soils were evaluated for their suitability for commonly grown crops (cotton, pigeon pea, wheat and chick pea) and mapping unit 2 and 4 were highly suitable for cotton cultivation and other were moderately to marginal suitable for other crops.
\end{abstract}

Keywords: West coast plain, detailed soil survey, mapping, soil classification, land evaluation

\section{Introduction}

Soil, water and vegetation need to be used and managed in an integrated and sustainable manner to meet the food and nutritional security for ever increasing population. These resources need to be precisely characterized and mapped for sustainable management. The high-spatial resolution remotely sensed data coupled with topographical data provides real time and accurate information related to distinct geological

*Corresponding author: (Email: gopalmpkv@gmail.com) formation and landforms. Soils vary in their morphological, physical and chemical properties in vertical and lateral directions (Wilding and Drees 1983). A vital knowledge of the kind of soils and their spatial distribution is a pre-requisite in developing rational soil map and land use plan for agriculture, forestry and irrigation (Biswas 1987). Evaluation of land units on the basis of their capabilities (under given circumstances including level of management and socio-economic conditions) is required to provide highest returns per unit area and conserving natural resources for future use (Van 
Wanbeke and Rossiter 1987). Today, efforts have been made in application of digital technology as a support system for precise and formidable land use planning (Sharma et al. 2018). Through present study an attempt has been made to identify different soils and their extent on a landscape, their morphological, physical and chemical characteristics in Valia block, Bharuch district in Gujarat.

\section{Materials and Methods}

The study was conducted in Valia block, Bharuch district of Gujarat $\left(21^{\circ} 31^{\prime} 8^{\prime \prime}\right.$ to $21^{\circ} 34^{\prime} 13^{\prime \prime} \mathrm{N}$, $73^{\circ} 03^{\prime} 12^{\prime \prime}$ to $73^{\circ} 20^{\prime} 53^{\prime \prime} \mathrm{E}$ ) and covers an area of 50,160 ha (Fig. 1). The area falls in Gujarat coastal plain physiographic region and west coast plain subphysiographic region, characterized by hot semi-arid (AESR 5.2) climate having ustic soil moisture regimes and hyperthermic soil temperature regimes. The mean annual temperature is $27^{\circ} \mathrm{C}$ with mean summer temperature of $31.1^{\circ} \mathrm{C}$ and mean winter temperature $14.7^{\circ} \mathrm{C}$. The relative humidity $(\mathrm{RH})$ ranges from 11 to 94 per cent. The rainfall (average $\approx 700 \mathrm{~mm}$ ) receives through south-west monsoon which normally starts from middle of June. August and September are the months of heavy rainfall. The soils of the area have their legacy with basaltic alluvium.
Detailed soil survey (1:10000 scale) was carried out using base map prepared from satellite data (IRS-P6 LISS IV and Cartosat-1), Digital Elevation Models (DEM) in conjunction with Survey of India (SOI) Toposheets of 1:50000 scale. The landforms, landscape ecological units (LEUs) and land use-land cover (LULC) were delineated by screen visual interpretation techniques based on key image elements such as shape, shadow, pattern, tone or colour, association and texture. Slope, hill-shade and contour $(10 \mathrm{~m})$ maps were prepared by using Cartosat-1 DEM (30 m) and landform map was generated by superimposing these maps. The landform, slope and LULC were overlaid over each other in Arc-GIS to generate LEU map (Singh et al. 2018).

Geo-referenced profile representing each landform was studied for their morphological properties (Soil Survey Staff 2014) and horizon-wise soil samples were collected and analyzed for physical and chemical analysis as per standard procedures (Page et al. 1982, Klute 1986). Based on the field observation in various landscape ecological units (LEUs) and correlation, six soil series were identified and mapped as phases of soil series into 10 mapping units. The soil-site suitability was worked out for pigeon pea, cotton, wheat and chick pea as per the methodology proposed by Sys et al. (1991) and Naidu et al. (2006).

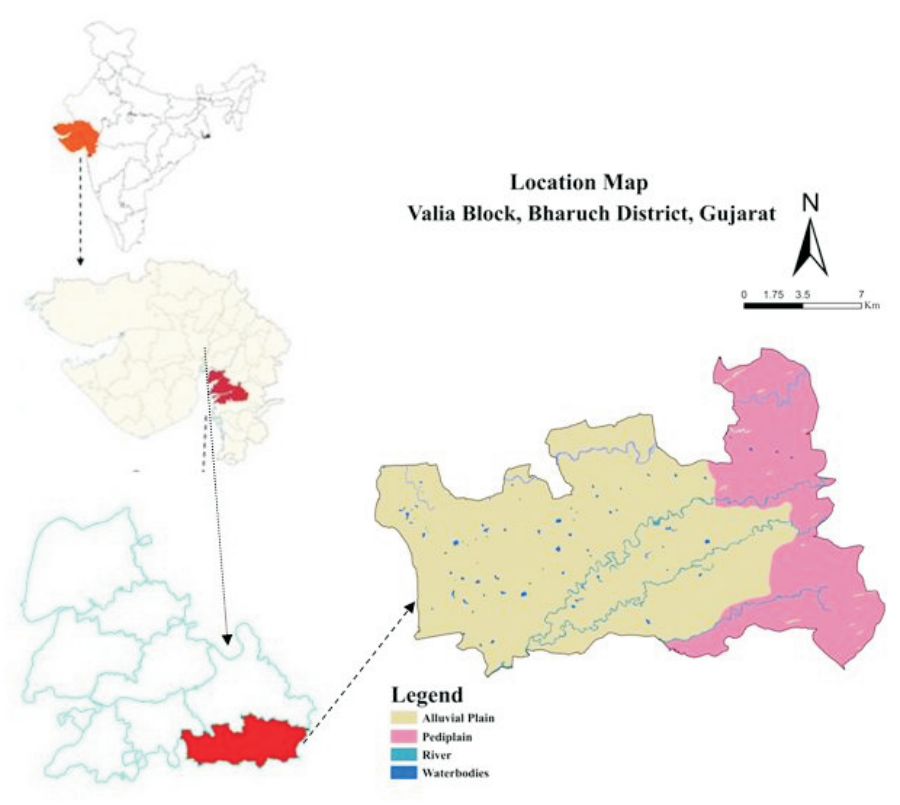

Fig. 1 Location and landform map of Valia block, Bharuch district, Gujarat 


\section{Results and Discussion}

\section{Morphological properties}

The details of the soil morphological properties of all representing pedons are presented in table 1 . The LEUs and soil map is depicted in fig. 2 and 3, respectively and soil legend is presented in table 4 and 5 . The solum depth of representative pedons varied from moderately deep to very deep $(>150 \mathrm{~cm})$ in alluvial plain and shallow $(25-50 \mathrm{~cm})$ in pediplain with texture ranging from silty clay loam to clay. The soils were well to moderately well drain barring pedon 4 . The soil colour

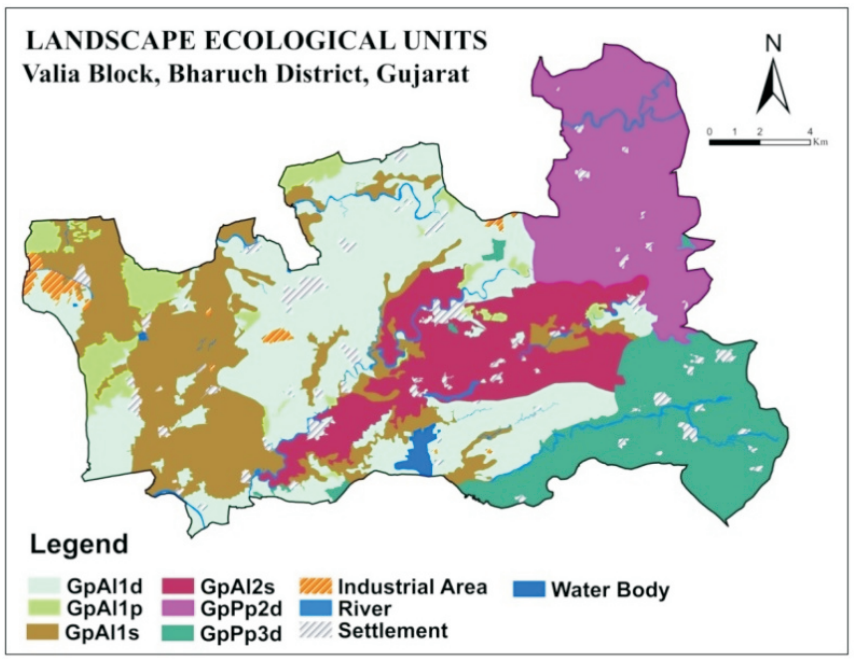

Fig. 2 Landscape ecological units (LEU) map of Valia block

\section{Physical properties}

Particle-size distribution data (Table 2) indicated that the sand, silt and clay contents varied among each series and ranged from 8.2 to $44.4,9.8$ to 40.2 and 43.8 to 55.6 per cent, respectively in surface horizons. There was an irregular distribution of soil fractions down the profile. Soils of pedon P4 and P5 showed a decreasing trend with depth for silt content while other soils showed irregular distribution pattern. Sub-surface clay (55.6\%) was high in soil of pedon P5 and increased with depth whereas other soils showed the irregular pattern of clay distribution. The increase in clay content with soil depth indicated illuviation of clay varied from very dark greyish brown (10YR3/2) on surface to dark yellowish brown (10YR3/4) in subsurface soils (P3) and dark greyish brown (10YR4/2) on surface to brown (10YR4/3) in sub-surface soils (P1).

Majority of surface soils (Ap horizon) had medium weak sub-angular blocky structure except pedon P2 and P4 wherein it was medium moderate subangular blocky, but sub-surface soils had medium moderate sub-angular blocky structure. Pedon P2 had medium moderate angular blocky structure due to presence of slickensides and pressure faces with high smectitic clay minerals (Pal et al. 2012).

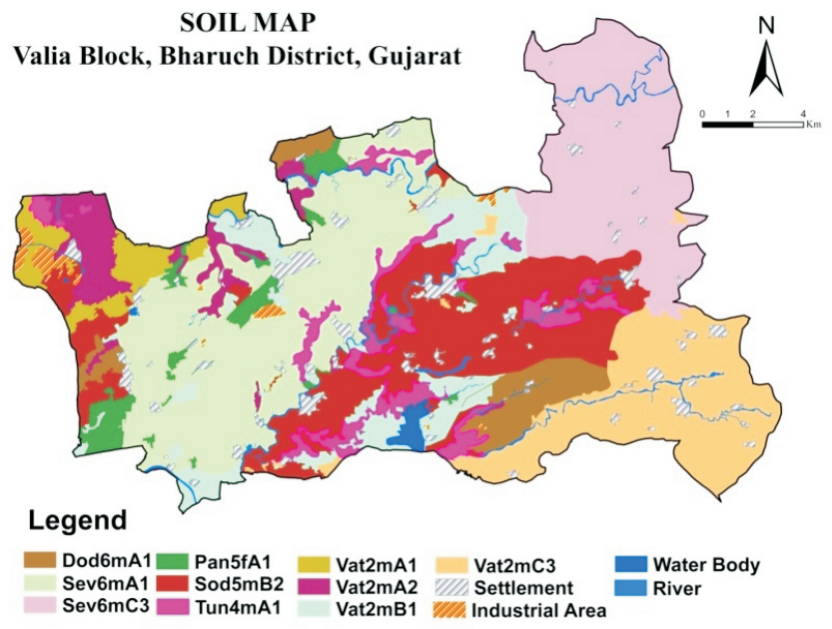

Fig. 3 Soil map of Valia block

from surface to sub-surface horizons (Bhattacharyya et al. 1998). The wide variation in particle-size distribution in soils of Valia block might be due to the deposition of soil materials in different time scale, topographical variations and weathering process (Basavaraju et al. 2005).

\section{Chemical characteristics}

Soils of pedons P1, P2, P3 and P6 were moderately alkaline ( $\mathrm{pH} 7.9-8.5$ ), pedon $\mathrm{P} 4$ was neutral (pH 6.8-7.3) whereas pedon P5 was strongly alkaline (pH 9.3-9.7). The electrical conductivity (EC) ranged from 0.10 to $1.6 \mathrm{dSm}^{-1}$. The organic carbon (OC) content 





Table 2. Physical properties of soils

\begin{tabular}{|c|c|c|c|c|}
\hline Horizon & Depth (cm) & Sand $(\%)$ & Silt $(\%)$ & Clay (\%) \\
\hline \multicolumn{5}{|c|}{ Pedon 1 :Pansoli series : Fine, smectitic, hyperthermic Vertic Haplustepts } \\
\hline Ap & $0-11$ & 33.2 & 23.0 & 43.8 \\
\hline Bw1 & $11-42$ & 48.4 & 13.2 & 38.4 \\
\hline Bw2 & $42-80$ & 43.1 & 18.1 & 38.8 \\
\hline $\mathrm{BC}$ & $80-120$ & 28.2 & 28.2 & 43.6 \\
\hline \multicolumn{5}{|c|}{ Pedon 2 :Dodwada series : Fine, smectitic, hyperthermic Typic Haplusterts } \\
\hline Ap & $0-15$ & 33.1 & 23.1 & 43.8 \\
\hline Bw1 & $15-65$ & 38.4 & 23.2 & 38.4 \\
\hline Bss 1 & $65-95$ & 43.3 & 8.2 & 48.5 \\
\hline $\mathrm{BC}$ & $95-150$ & 23.0 & 43.2 & 33.8 \\
\hline \multicolumn{5}{|c|}{ Pedon 3 :Tuna series : Fine, mixed, hyperthermic Typic Calciustepts } \\
\hline Ap & $0-15$ & 8.2 & 40.2 & 55.6 \\
\hline Bk1 & $15-53$ & 33.1 & 20.4 & 40.5 \\
\hline $\mathrm{Bk} 2$ & $53-70$ & 8.3 & 41.3 & 50.4 \\
\hline $\mathrm{BC}$ & $70-95$ & 28.2 & 26.4 & 45.4 \\
\hline \multicolumn{5}{|c|}{ Pedon 4 :Sodam series : Fine, mixed, hyperthermic Typic Haplustepts } \\
\hline Ap & $0-15$ & 28.2 & 21.2 & 50.6 \\
\hline Bw1 & $15-40$ & 38.3 & 21.4 & 40.3 \\
\hline Bw2 & $40-70$ & 43.4 & 16.4 & 40.2 \\
\hline $\mathrm{BC}$ & $70-110$ & 5.3 & 11.4 & 35.6 \\
\hline \multicolumn{5}{|c|}{ Pedon 5 :Sevad series : Fine, smectitic, hyperthermic Sodic Haplusterts } \\
\hline Ap & $0-15$ & 44.4 & 9.8 & 45.8 \\
\hline Bw1 & $15-35$ & 44.2 & 5.1 & 50.7 \\
\hline Bss 1 & $35-65$ & 39.6 & 4.8 & 55.6 \\
\hline Bss2 & $65-96$ & 44.8 & 4.6 & 50.6 \\
\hline $\mathrm{BC}$ & $96-150$ & 39.5 & 5.0 & 55.5 \\
\hline \multicolumn{5}{|c|}{ Pedon 6 :Vatariya series : Fine, mixed, hyperthermic Lithic Haplustepts } \\
\hline Ap & $0-15$ & 34.4 & 14.5 & 50.9 \\
\hline $\mathrm{BC}$ & $15-49$ & 34.2 & 19.9 & 45.9 \\
\hline
\end{tabular}

in the surface soils varied from 0.18 to 1.2 per cent and it decreased with the depth except pedons P1, P5 and P6. This could be attributed to the addition of plant residues and farmyard manure to the surface horizon. Calcium carbonate equivalent $\left(\mathrm{CaCO}_{3}\right)$ ranged from 5.9 per cent (P2) to 26.6 per cent (P3) and increased with depth in all the soils except pedon $\mathrm{P} 1$. The cation exchange capacity (CEC) and base saturation percentage (BSP) ranged from 34.2 to 83.4 [cmol $\left(\mathrm{p}^{+}\right) \mathrm{kg}^{-1}$ ] and 70.9 to 99.4 per cent, respectively (Table 3). Among the exchangeable cations, $\mathrm{Ca}^{2+}$ and $\mathrm{Mg}^{2+}$ were the dominant cations followed by $\mathrm{Na}^{+}$and $\mathrm{K}^{+}$. The exchangeable sodium percentage (ESP) and exchangeable magnesium percentage (EMP) ranged from 0.7 to 39.6 and 8.6 to 40 per cent, respectively. High ESP in soils of pedon P5 series was due to the sea water intrusion and irrigation with underground water. Similar findings were also observed by Nayak et al. (2000) and Chinchmalatpure et al. (2008) in salt affected soils of Gujarat. The high EMP in majority of soils was attributed by magnesium rich basaltic parent material. 


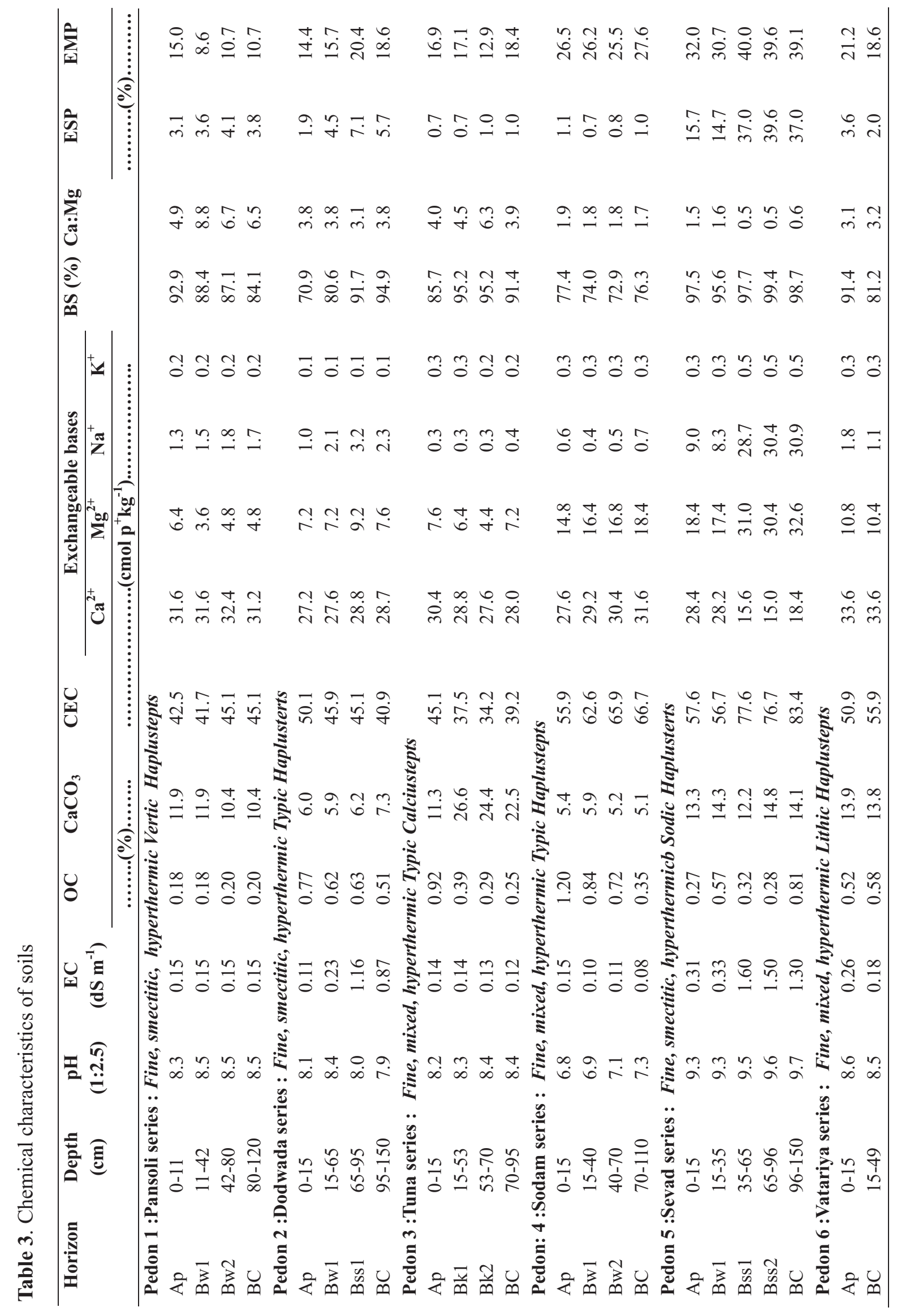




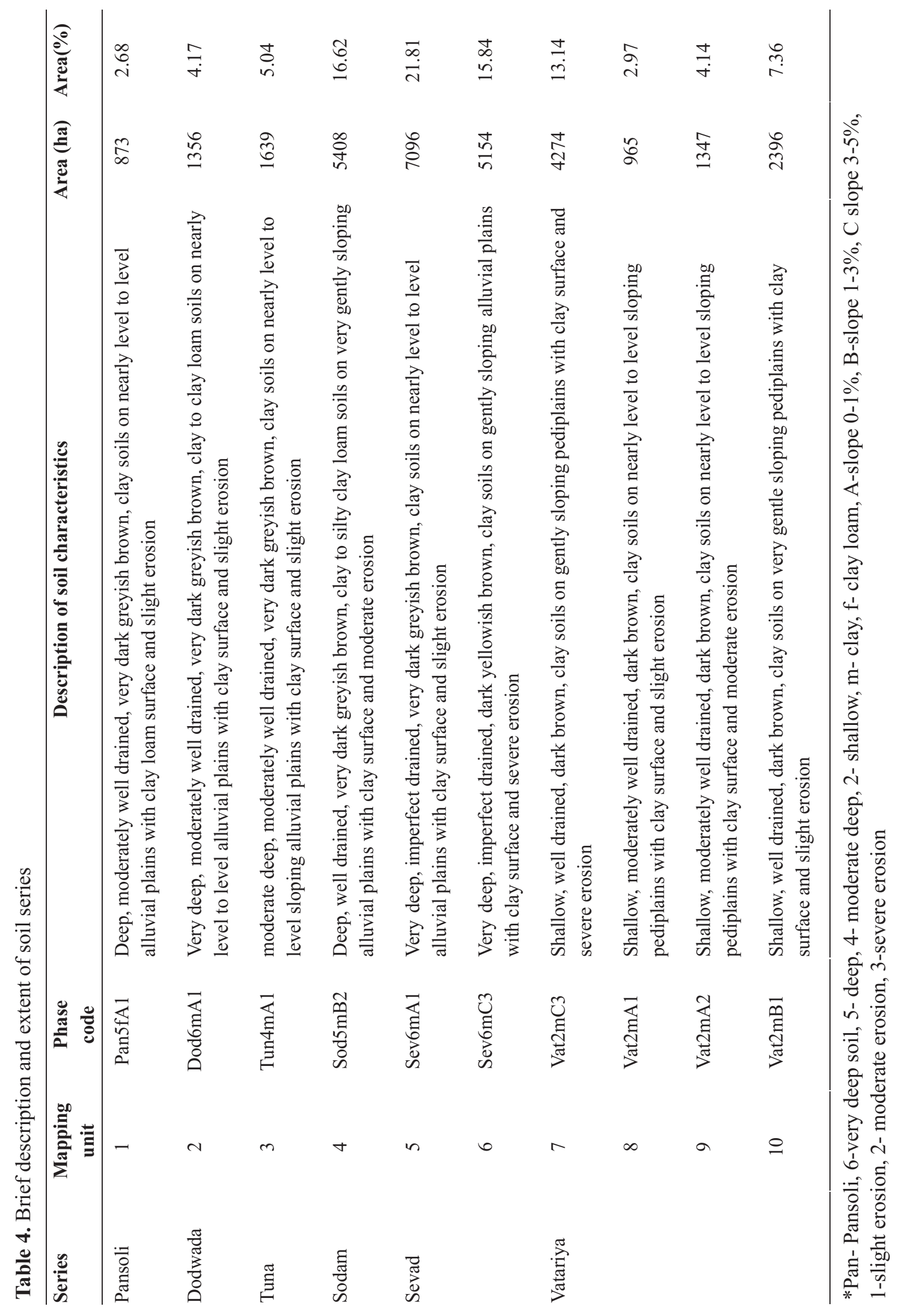




\section{Soil Classification}

Soils of Pansoli (P1), Sodam (P4) and Vatariya (P6) had cambic and Tuna (P3) had calcic sub-surface diagnostic horizons and classified as Inceptisols soil order. Pedons P1, P4 and P6 were grouped under Ustepts sub-order due to Ustic soil moisture regime and Haplustepts great group because these pedons did not show either duripan or calcic horizon and base saturation was more than $60 \%$ at a depth between 0.25 to $0.75 \mathrm{~m}$ from the surface. Pedon P4 did not exhibit any intergradations with other taxa or an extra gradation from the central concept. Hence, it was logically classified as Typic Haplustepts. Pedon P6 was placed under Lithic Haplustepts at sub-group level due to the presence of lithic contact within $50 \mathrm{~cm}$ of the mineral soil surface. Pedon P1 was placed under Vertic Haplustepts at sub group level due to presence of cracks within $125 \mathrm{~cm}$ of the mineral soil surface that are $5 \mathrm{~mm}$ or more wide through a thickness of $30 \mathrm{~cm}$ or more for some time in normal years and wedge shaped peds in a layer $15 \mathrm{~cm}$ or more thick that has its upper boundary within $125 \mathrm{~cm}$ of the mineral soil surface. Pedon P3 was placed under Typic Calciustepts at sub group level due to the presence of calcic sub-surface diagnostic horizon $(>15 \mathrm{~cm}$ thick with $\mathrm{CaCO}_{3}$ ) within $100 \mathrm{~cm}$ of mineral soil surface. Dodwada (P2) and Sevad (P5) showed slickensides, wedge shaped aggregates, clay $(>30 \%)$ in all the horizons and cracks ( $3-4 \mathrm{~cm}$ wide and $>30 \mathrm{~cm}$ deep) in the $\mathrm{B}$ horizon and classified as Vertisols soil order. Dodwada (P2) classified as Typic Haplusterts at sub group level on the basis of ustic SMR and relevant typifying properties and classified as fine, smectitic, hyperthermic Typic Haplusterts at family level. Sevad (P5) was placed under Sodic Haplusterts at sub-group level due to presence of one or more horizons within 100 $\mathrm{cm}$ of the mineral soil surface, an exchangeable sodium percentage of 15 or more (or a sodium adsorption ratio of 13 or more) for 6 or more months in normal years and classified as fine, smectitic, hyperthermic Sodic Haplusterts at family level.

Table 5. Brief description of LEU of Valia block

\begin{tabular}{lllll}
\hline Physiography & $\begin{array}{l}\text { Sub- } \\
\text { physiography }\end{array}$ & $\begin{array}{l}\text { Broad } \\
\text { landform }\end{array}$ & LEUs & Slope and land use \\
\hline $\begin{array}{l}\text { Gujarat coastal } \\
\text { plain }(\mathrm{G})\end{array}$ & West coast plain & Pediplain & $\mathrm{GpPp} 2 \mathrm{~d}$ & Very gently pediplain (double crop) \\
& $(\mathrm{p})$ & $\mathrm{Pp})$ & $\mathrm{GpP} 3 \mathrm{~d}$ & Gently sloping pediplain (double crop) \\
& Alluvial & $\mathrm{GpA}_{1} 1 \mathrm{~d}$ & Nearly level alluvial plain (double crop) \\
& Plains $\left(\mathrm{A}_{1}\right)$ & $\mathrm{GpA}_{1} 1 \mathrm{p}$ & Nearly level alluvial plain (pasture land) \\
& & $\mathrm{GpA}_{1} 1 \mathrm{~s}$ & Nearly level alluvial plain (single crop) \\
& & $\mathrm{GpA}_{1} 2 \mathrm{~s}$ & Very gently alluvial plain (single crop) \\
\hline
\end{tabular}

\section{Soil Suitability for Crops}

Out of the ten mapping units, six units (5 to 10) were found marginally suitable for the cotton, pigeon pea, wheat and chick pea (Table 6) due to the limitation of soil depth and erosion (mapping units 7, 8,9 and 10) and high ESP (mapping units 5 and 6). Mapping unit 1, 2, 3 and 4 were moderately suitable for pigeon pea, wheat and chick pea. Mapping units of Pansoli and
Dodwada series of (mapping units 1 and 2) were evaluated as highly suitable for cotton cultivation (Table 6). The cultivation of these crops as per their suitability of soils can support the sustainable crop production without any adverse impact on soil health of Valia taluka. 
Table 6. Soil Suitability for major crops

\begin{tabular}{ccccc}
\hline $\begin{array}{c}\text { Mapping unit } \\
\text { no. }\end{array}$ & Cotton & Pigeon pea & Wheat & Chick pea \\
\hline 1 & $\mathrm{~S} 2$ & $\mathrm{~S} 2$ & $\mathrm{~S} 2$ & $\mathrm{~S} 2$ \\
2 & $\mathrm{~S} 1$ & $\mathrm{~S} 2$ & $\mathrm{~S} 2$ & $\mathrm{~S} 2$ \\
3 & $\mathrm{~S} 2$ & $\mathrm{~S} 2$ & $\mathrm{~S} 2$ & $\mathrm{~S} 2$ \\
4 & $\mathrm{~S} 1$ & $\mathrm{~S} 2$ & $\mathrm{~S} 2$ & $\mathrm{~S} 2$ \\
5 & $\mathrm{~S} 3$ & $\mathrm{~S} 3$ & $\mathrm{~S} 3$ & $\mathrm{~S} 3$ \\
6 & $\mathrm{~S} 3$ & $\mathrm{~S} 3$ & $\mathrm{~S} 3$ & $\mathrm{~S} 3$ \\
7 & $\mathrm{~S} 3$ & $\mathrm{~S} 3$ & $\mathrm{~S} 3$ & $\mathrm{~S} 3$ \\
8 & $\mathrm{~S} 3$ & $\mathrm{~S} 3$ & $\mathrm{~S} 3$ & $\mathrm{~S} 3$ \\
9 & $\mathrm{~S} 3$ & $\mathrm{~S} 3$ & $\mathrm{~S} 3$ & \\
\hline
\end{tabular}

\section{Summary}

It can be concluded that the soils of Valia block were neutral to strongly alkaline in reaction, non-saline and low to high in organic carbon with high CEC and base saturation. The soils were classified as Vertic Haplustepts, Typic Haplusterts, Sodic Haplusterts, Typic Calciustepts, Typic Haplustepts and Lithic Haplustepts. The majority soils of the area are moderately to marginal suitable for cotton, pigeonpea, wheat and chickpea. This information can help the farmers, researchers and planners to sustain the natural resources and enhance the productivity of soils of Valia block.

\section{References}

Basavaraju, D., Naidu, M. V. S., Ramavatharam, N., Venkaiah, K., Rama Rao, G. and Reddy, K. S. (2005). Characterization, classification and evaluation of soils in Chandragiri Mandal of Chittoor district, Andhra Pradesh. Agropedology 15, 55-62.

Bhattacharyya, T., Mukhopadhyoy, S., Buruah, U. and Chamuah, G. S. (1998). Need of soil study to determine degradation and landscape stability. Current Science 74, 42-47.

Biswas, R. R. (1987). A soil map through landsat satellite imagery in part of the Auranga catchment in the Ranchi and Palamou districts of Bihar, India. International Journal of Remote Sensing 8, 541-543.
Chinchmalatpure, A. R., Khandelwal, M. K. and Rao, G. G. (2008). Characterization and classification of salt affected soils of Samni farm, Bharuch district, Gujarat. Agropedology 18, 71-75.

Klute, A. (1986). Methods of soil analysis. Part 1. (American Society of Agronomy and Soil Science Society of America. Madison: Wisconsin)

Naidu, L. G. K., Ramamurthy, V., Challa, O., Hegde, R. and Krishnan, P. (2006). Manual Soil-site suitability criteria for major crops. National Bureau of Soil Survey and Land Use Planning, Technical Publication No. 129, Nagpur.

Nayak, A. K., Rao, G. G., Chinchmalapture, A. R. and Singh, R. (2000). Characterization and classification of some salt affected soils of Bhal region of Gujarat. Agropedology 10,152-162.

Page, A. L., Miller, R. H. and Keeney, D. R. (1982). Methods of soil analysis. Part 2. In 'Chemical and Microbiological Properties', (Second Edition) pp.9 (Madison, WI, USA).

Pal, D. K., Wani, S. P.and Sahrawat, K. L. (2012). Vertisols of tropical Indian environments: pedology and edaphology. Geoderma 189, 28-49.

Sharma, R. P., Singh, R. S., Singh, S. K. and Arora, S. (2018). Land resource inventory (LRI) for development of sustainable agricultural land use plans using geospatial techniques: A case study of Pata Meghpar village, Jamnagar district, Gujarat. Journal of Soil and Water Conservation 17, 15-24.

Singh, S. K., Chattaraj, S., Singh, R. S., Ramamurthy, V., Banddhopadhyay, S., Sharma, R. P., Gosh, B. N., 
Sah, K. D., Butte, P.S. and Mukhopadhyay, S. (2018). Book chapter 'LRI technology-A base for sustainable agriculture'. NBSS Publ. No. 176, pp 1-32.

Soil Survey Staff(2014). Keys to Soil Taxonomy. Twelth Edition. (Natural Resource Conservation Service, USDA: Washington, DC).

Sys, C. E., Van Ranst, E. and Debayeve, J. (1991). Land Evaluation, Part I and II. Publication No.7. (General Administration of Cooperation and Development, Brussels, Belgium).
Van Wanbeke, A. and Rossiter, D. (1987). Automated land evaluation systems as a focus for soil research. IBSRAM, Newsletter 6.

Wilding, L. P. and Drees, L. R. (1983). Spatial variability and pedology. In 'Pedogenesis and Soil Taxonomy: Concept and Interaction, Vol. I'. (Eds. L. P. Wilding, N. E. Smeck and G. F. Hall) pp.83113. (Elsevier Scientific Publishing, New York).

Received: December, 2017 Accepted: June, 2018 